\title{
January Effect Revisited: Evidence from Borsa Istanbul and Bucharest Stock Exchange
}

\author{
Serkan Sahin ${ }^{1}$, Emre Esat Topaloglu ${ }^{2} \&$ Ilhan Ege ${ }^{3}$ \\ ${ }^{1}$ Department of Business Administration, Kahramanmaras Sutcu Imam University, Kahramanmaras, Turkey \\ ${ }^{2}$ Department of Business Administration, Sirnak University, Sirnak, Turkey \\ ${ }^{3}$ Department of Business Administration, Mersin University, Mersin, Turkey \\ Correspondence: Serkan Sahin, Department of Business Administration, Kahramanmaras Sutcu Imam University, \\ Kahramanmaras, Turkey. Tel: 90-344-300-1342. E-mail: serkansahin@ksu.edu.tr
}

Received: May 5, 2015

doi:10.5539/ijef.v10n1p159
Accepted: October 12, $2016 \quad$ Online Published: December 15, 2017

URL: https://doi.org/10.5539/ijef.v10n1p159

\begin{abstract}
Any siginificant deviation from fundamental value observed in a market is acctepted to be an anomaly. As one of the most commonly referred anomalies in markets, January effect may be used to explain abnormal stock returns observed in January. The aim of this paper is to examine the January effect in two emerging markets for the time period between 2000 and 2014 using daily closing prices with power ratios analysis. Our results indicate that January effect is persistent for both Borsa Istanbul (BIST-100) and Bucharest Stock Exchange (BET).
\end{abstract}

Keywords: efficient market hypothesis, BIST-100, BET, return anomalies, January effect

\section{Introduction}

Efficient Market Hypothesis (EMH) states that prices reflect all available information in a given market. In this manner, the efficiency of the market is related to the speed of the price adjustment mechanism to the arrival of new information in a market. In other words, if the prices in a market respond quickly to the newly arrived information, that market is efficient. This means that investors in that market cannot earn abnormal return consistently in that market (Karan, 2004, pp. 271-273). However, it is seen that many observed price changes are contraray to the assumptions of EMH. These observed abnormal returns can be explained by calendar and return anomalies. Calendar anomalies may show up either daily, weekly, monthly or annually, whereby return anomalies come up as over or under reaction referring to the deviations from true value. If there is consistent abnormal return in January, it is highly possible to be explained by the so called January effect. It is accepted that there are many reasons for the existence of January effect. First, it is possible that there is higher risk in January which allow investors to get excess returns in January. Another reason may be the tax-loss selling hypothesis which induce that investors to realize their losses before the end of the year. Another reason may be the increasing demand to the stocks in a market due to the arrival of new information in January and the increasing money supply in this month as a result (Özer \& Özcan, 2002, pp. 136-138).

The purpose of this paper is to examine the January effect in Borsa Istanbul-100 and Bucharest Exchange Trading indices for the time period 2000-2014. Power raito analysis are used to examine the January effect for these two emerging markets.The rest of this paper structured as follows. A summary of the literature about EMH and January effect is given in Section 2. Data and methodology is explained in Section 3. Empirical results are presented in Section 4 and finally, conclusions and policy implications are summarized in Section 5.

\section{A Brief Literature Review}

Though there is vast literature examining the January effect, there is no common point on the validity of January effect especially in emerging markets. It is seen that the majority of these studies differ interms of the countries analyzed, time period used and empirical findings reached. In one of these studies, it is found that investors get abnormal return in January and this excess return is higher for low value stocks (Wachtel, 1942, pp. 185-188). It is also reported that returns in Australia stock exchange are quite higher (Officer, 1975, p. 29). In another study, it is concluded that returns in January are much higher in New York Stock Exchange for the time period 1904-1974 (Rozeff \& Kinney, 1976, p. 379). 
In a study called "A Tax Loss Trading Rule", it is concluded that returns in January are considerably high and returns of small firms are even higher than the average (Branch, 1977, pp. 200-202). In a study by Dyl (1977, pp. 170-174), it is found that returns of smaller firms have higher rates of returns than larger firms and concluded that tax-loss selling hypothesis is the rationale for the existence of the January effect.

It is mainly argued that anomalies in January mainly arise due to the firms that made loss in the last year (Reinganum, 1983). January effect is validated for many markets such as Montreal and Toronto Stock Exchange (Berges et al., 1984), Amsterdam (Van Den Bergh \& Wessels, 1985), Madrid Stock Exchange (Santesmases, 1986), Bruxelles, London, New York and Paris (Corhay et al., 1987), Philippines (Aggarwal \& Tandon, 1994), Amman Stock Exchange (Alrabadi \& Al-Qudah, 2012), Borsa İstanbul (Aytekin \& Sakarya, 2014), United Kingdom, Singapur, U.S.A, Malaysia, Taiwan and Hong Kong Stock Exchange Markets (Ho, 1990).

There are also some other studies reporting contradicatory findings. In one of these studies it is concluded that though January effect exists, it is not persistent (Özer \& Özcan, 2002, p. 153). It is also found in this study that firm size can not explain abnormal returns observed in January. Though, January effect is validated for the main index of Borsa Istanbul, it cannot be verified for sub-indices such as XUGIDA, XUMALI and XUHOLD in this market (Küçüksille, 2012, p. 129). In a study using daily data for the period 1989-2006, it is concluded that January effect does not exist for Borsa Istanbul (Çinko, 2008, p. 47). In another study, January effect cannot be validated 17 of 19 countries analyzed (Bohl \& Salm, 2010, p. 173). It is concluded in this study that January effect is not a consistent international phenomenon anymore. In a another study, it is reported that January effect is not persistent for Hong Kong, India, Indonesia, Japan, Malaysia, Korea, Philippines, Singapore, Taiwan, China and Thailand (Keong et al., 2010). It is seen that there is no common point of view for the existance of January effect especially in emerging arkets.

\section{Data and Methodology}

BIST-100 and Bucharest Stock Exchange Trading (BET) daily closing prices for the time period 2000-2014 are used to examine the January effect. Return data are gathered from the official web sites of Borsa Istanbul (BIST) (www.borsaistanbul.com) and Bucharest Exchange Trading (BET) (www.bvb.ro). Monthly returns are calculated for each year starting from 2000 to 2014 using eqn. 1 below and average annual returns are estimated using returns of remaining months of the year. In addition, all data are used in natural logarithms.

$$
R_{p}=\ln P_{t}-\ln P_{t-1}
$$

Where $R_{p}$ is the period return rate, $P_{t}$ is the closing price of the index in period $t$ and $P_{t-1}$ closing price of the index in period $t-1$.

The advantage of the this approach is that it enables making analysis when the return of January and other months have different signs. In order to calculate the power ratio, $R_{j}$ and $R_{y}$ are first calculated as shown in eqn. (2) and (3) below (Gu, 2003, p. 397);

$$
\begin{aligned}
& R_{j}=\left(1+R_{m j}\right)^{12} \\
& \mathrm{R}_{\mathrm{y}}=\left(1+\mathrm{R}_{\mathrm{a}}\right)
\end{aligned}
$$

After that, power ratio can be estimated by dividing the $R_{j}$ to $R_{y}$ Where $R_{m j}$ is the return in January and $R_{a}$ is the return of the year. As it's seen in eqn. (2), $R_{j}$ in every case results in a positive number. Similarly, $R_{y}$ which accounts for the return of the year is always greater than zero (Gu, 2003, p. 397).

In order to investigate the Janaruary effect, one should examine the power ratios in this method. In particular, there are three different cases. First, if $R_{j}$ is greater than $R_{y}$, which means that return in January is larger than the return of remaining months, January effect may exist in that market. If $R_{y}$ is greater than $R_{j}$, which means that return of the remaining months is larger than the return in January. Finally, if the return in January just equal to the return of the remaining months, the ratio gets the exact value of 1 . Hence in our analysis power ratios are estimated starting from the year 2000 to 2014 both for BIST-100 and BET indices, which results in fifteen different power ratios for each of the indices. In order to validate the existence of January effect in our analysis, for at least eight of the fifteen cases $R_{j}$ should be greater than $R_{y}$. The results are shown in Section 4 .

\section{Results}

Natural logarithms of all returns which are calculated using daily closing prices of BIST and BET indices are presented in Table 1 and Table 2 respectively. At first glance, it is seems that returns in January for both BIST and BET indices are quite higher than most of the return series of the remaining months for the time period analyzed. 
Table 1. BET index returns

\begin{tabular}{rrrrrrrrrrrrrr}
\hline & $\underline{\mathbf{1}}$ & $\underline{\mathbf{2}}$ & $\underline{\mathbf{3}}$ & $\underline{\mathbf{4}}$ & $\underline{\mathbf{5}}$ & $\underline{\mathbf{6}}$ & $\underline{\mathbf{7}}$ & $\underline{\mathbf{8}}$ & $\underline{\mathbf{9}}$ & $\underline{\mathbf{1 0}}$ & $\underline{\mathbf{1 1}}$ & $\underline{\mathbf{1 2}}$ & $\underline{\text { Mean }}$ \\
\hline $\mathbf{2 0 0 0}$ & 0.272 & -0.045 & -0.108 & -0.048 & 0.035 & 0.027 & 0.090 & -0.192 & 0.064 & 0.039 & -0.040 & 0.080 & $\mathbf{0 . 0 1 5}$ \\
$\mathbf{2 0 0 1}$ & 0.066 & -0.030 & -0.083 & -0.019 & 0.006 & 0.094 & 0.024 & 0.137 & -0.108 & 0.011 & 0.022 & 0.005 & $\mathbf{0 . 0 1 0}$ \\
$\mathbf{2 0 0 2}$ & -0.006 & 0.011 & 0.056 & 0.279 & 0.010 & -0.011 & 0.042 & 0.107 & 0.129 & -0.019 & -0.064 & 0.038 & $\mathbf{0 . 0 4 8}$ \\
$\mathbf{2 0 0 3}$ & 0.046 & -0.017 & -0.033 & 0.023 & 0.046 & 0.022 & -0.008 & -0.003 & 0.038 & -0.016 & 0.079 & 0.082 & $\mathbf{0 . 0 2 2}$ \\
$\mathbf{2 0 0 4}$ & 0.050 & 0.076 & 0.087 & -0.129 & 0.069 & 0.048 & 0.035 & -0.042 & 0.023 & 0.214 & 0.124 & 0.084 & $\mathbf{0 . 0 5 3}$ \\
$\mathbf{2 0 0 5}$ & 0.206 & 0.133 & -0.240 & -0.105 & -0.079 & -0.011 & 0.152 & -0.004 & 0.069 & -0.016 & 0.071 & 0.001 & $\mathbf{0 . 0 1 5}$ \\
$\mathbf{2 0 0 6}$ & 0.207 & 0.001 & -0.044 & 0.057 & -0.063 & -0.005 & 0.066 & 0.016 & 0.021 & 0.047 & 0.009 & 0.009 & $\mathbf{0 . 0 2 7}$ \\
$\mathbf{2 0 0 7}$ & -0.002 & 0.010 & -0.007 & 0.058 & 0.002 & 0.150 & 0.049 & 0.006 & -0.044 & 0.019 & -0.135 & 0.080 & $\mathbf{0 . 0 1 6}$ \\
$\mathbf{2 0 0 8}$ & -0.265 & 0.005 & 0.004 & 0.010 & 0.092 & -0.194 & -0.037 & -0.166 & -0.329 & -0.498 & -0.020 & 0.057 & $\mathbf{- 0 . 1 1 2}$ \\
$\mathbf{2 0 0 9}$ & -0.401 & -0.180 & 0.280 & 0.248 & 0.166 & -0.021 & 0.129 & 0.048 & 0.079 & 0.043 & 0.107 & -0.080 & $\mathbf{0 . 0 3 5}$ \\
$\mathbf{2 0 1 0}$ & 0.061 & 0.014 & 0.099 & -0.079 & -0.222 & -0.051 & 0.148 & -0.067 & 0.118 & 0.005 & -0.104 & 0.034 & $\mathbf{- 0 . 0 0 4}$ \\
$\mathbf{2 0 1 1}$ & 0.083 & 0.048 & 0.073 & 0.058 & -0.109 & -0.033 & -0.041 & -0.114 & -0.186 & 0.124 & -0.088 & -0.037 & $\mathbf{- 0 . 0 1 9}$ \\
$\mathbf{2 0 1 2}$ & 0.090 & 0.105 & 0.019 & -0.008 & -0.133 & -0.052 & 0.050 & 0.034 & -0.015 & 0.029 & -0.024 & 0.049 & $\mathbf{0 . 0 1 2}$ \\
$\mathbf{2 0 1 3}$ & 0.109 & -0.004 & 0.017 & -0.058 & 0.022 & -0.028 & 0.020 & 0.093 & -0.014 & 0.011 & 0.040 & 0.032 & $\mathbf{0 . 0 2 0}$ \\
$\mathbf{2 0 1 4}$ & 0.028 & -0.021 & -0.021 & 0.031 & -0.005 & 0.049 & 0.014 & 0.015 & 0.018 & -0.059 & 0.037 & -0.042 & $\mathbf{0 . 0 0 4}$ \\
Mean & $\mathbf{0 . 0 3 6}$ & $\mathbf{0 . 0 0 7}$ & $\mathbf{0 . 0 0 7}$ & $\mathbf{0 . 0 2 1}$ & $\mathbf{- 0 . 0 1 1}$ & $\mathbf{- 0 . 0 0 1}$ & $\mathbf{0 . 0 4 9}$ & $\mathbf{- 0 . 0 0 9}$ & $\mathbf{- 0 . 0 0 9}$ & $-\mathbf{- 0 . 0 0 4}$ & $\mathbf{0 . 0 0 1}$ & $\mathbf{0 . 0 2 6}$ & \\
\hline
\end{tabular}

It is seen in Table 1 that the highest return in 2000 for BET index was in January by $27.2 \%$, whereas the lowest rate recorded was in August by $-19.2 \%$ in 2000. The highest return for the BIST-100 index in the same year was in December with a rate of $18.2 \%$ whereas the lowest rate was recorded in February by $-51.4 \%$. In 2001, the highest of return for BET index was in in August by $13.7 \%$, the lowest rate was in September by $-10.8 \%$. For BIST index, the highest rates of returns was recorded in April by $43.3 \%$, whereas the lowest was in August with a rate of $57.7 \%$. In 2002, the highest returns were in April by $27.9 \%$ for BET index, and in December by $35.3 \%$ for BIST-100 respectively. Lowest returns in 2002 were in November by $-6.4 \%$ and in December by $-33.4 \%$ respectively.

Table 2. BIST-100 index returns

\begin{tabular}{|c|c|c|c|c|c|c|c|c|c|c|c|c|c|}
\hline & 1 & 2 & $\underline{3}$ & 4 & 5 & 6 & 7 & 8 & 9 & 10 & 11 & 12 & Mean \\
\hline 2000 & -0.074 & -0.514 & -0.105 & 0.167 & -0.169 & -0.155 & -0.059 & -0.096 & -0.156 & 0.147 & -0.476 & 0.182 & -0.109 \\
\hline 2001 & 0.110 & -0.499 & -0.268 & 0.433 & -0.164 & -0.096 & -0.205 & -0.570 & -0.329 & 0.214 & 0.249 & 0.213 & -0.076 \\
\hline 2002 & 0.038 & -0.255 & 0.051 & -0.007 & -0.160 & -0.171 & -0.003 & -0.071 & -0.079 & 0.120 & 0.353 & -0.334 & -0.043 \\
\hline 2003 & 0.048 & 0.066 & -0.100 & 0.242 & 0.079 & -0.056 & -0.023 & 0.115 & 0.114 & 0.094 & -0.111 & 0.189 & 0.055 \\
\hline 2004 & -0.065 & 0.103 & 0.076 & -0.201 & -0.076 & 0.075 & 0.061 & -0.007 & 0.068 & 0.072 & 0.015 & 0.150 & 0.023 \\
\hline 2005 & 0.078 & 0.055 & -0.136 & -0.118 & 0.057 & 0.085 & 0.077 & 0.013 & 0.037 & -0.060 & 0.145 & 0.044 & 0.023 \\
\hline 2006 & 0.132 & 0.047 & -0.127 & 0.014 & -0.316 & -0.085 & 0.074 & 0.075 & -0.038 & 0.129 & -0.060 & 0.048 & -0.009 \\
\hline 2007 & 0.051 & -0.030 & 0.119 & 0.048 & 0.123 & 0.015 & 0.120 & -0.014 & 0.151 & 0.084 & -0.060 & 0.036 & 0.054 \\
\hline 2008 & -0.253 & -0.018 & -0.175 & 0.092 & -0.013 & -0.133 & 0.301 & -0.093 & -0.134 & -0.398 & -0.112 & 0.140 & -0.066 \\
\hline 2009 & -0.107 & -0.073 & 0.113 & 0.241 & 0.113 & 0.024 & 0.172 & 0.019 & 0.034 & -0.013 & -0.038 & 0.146 & 0.053 \\
\hline 2010 & 0.022 & -0.146 & 0.112 & 0.047 & -0.124 & 0.011 & 0.140 & -0.031 & 0.129 & 0.064 & -0.110 & -0.035 & 0.007 \\
\hline 2011 & -0.099 & -0.063 & 0.132 & 0.067 & -0.145 & -0.020 & -0.056 & -0.184 & 0.011 & 0.003 & -0.036 & -0.083 & -0.039 \\
\hline 2012 & 0.109 & 0.060 & 0.028 & -0.039 & -0.085 & 0.127 & 0.027 & 0.047 & -0.015 & 0.088 & 0.007 & 0.068 & 0.035 \\
\hline 2013 & 0.007 & 0.007 & 0.080 & 0.002 & -0.001 & -0.120 & -0.039 & -0.100 & 0.115 & 0.041 & -0.024 & -0.111 & -0.012 \\
\hline 2014 & -0.092 & 0.011 & 0.109 & 0.058 & 0.071 & -0.010 & 0.046 & -0.023 & -0.069 & 0.073 & 0.067 & -0.005 & 0.020 \\
\hline Mean & -0.006 & -0.083 & -0.006 & 0.070 & -0.054 & -0.034 & 0.042 & -0.061 & -0.011 & 0.044 & -0.013 & 0.043 & \\
\hline
\end{tabular}

The highest return rate was in December by $8.2 \%$ for BET index, whereas the lowest rate of return was recorded in March (-3.3\%) in 2003. For BIST-100 index, lowest return was in November $(-11.1 \%)$, and the highest rates of returns was in April (-24.2\%) for the same year. In 2004, the highest returns were in October (21.4\%) for BET index, and in April (20.1\%) for BIST-100 respectively. Whereas lowest returns in 2004 for both of the indices were in April. In 2005 and 2006, the highest returns were in January for BET index. The lowest return recorded was in March with a rate of $-24 \%$ in 2005, whereas it was in May with a rate of $-6.3 \%$ in 2005. For BIST-100 index, the highest rate of return was in November (14.5\%) in 2005, and the lowest rate was in March (-13.6\%). Surprisingly, the lowest return rate was recorded in January in 2006, whereas highest return was in May.

In 2007, monthly return in June was at its highest with a rate of $15 \%$, whereas return rates hit its lowest in 
November $(-13.5 \%)$ for BET index. BIST-100 index return dropped to its lowest level in November, whereas returns achieved its highest in September in 2007. In, 2008, BET and BIST-100 return rates recorded their highest in June and July respectively. However, returns dropped to its lowest rate in November and October. It is seen that average returns were remarkably lower in 2008 compared to other year's analzyed. We think that the lower return rates recorded in 2008 arise from the Global financial crisis happened in this year. It is seen that BET and BIST index recorded a loss of average $-9.8 \%$ and $-4.9 \%$ respectively in 2008 .

In 2009, BET index achieved its highest return in March (28\%), whereas index dropped to its lowest with a return of $-40.1 \%$ in January. In the same year, the lowest and highest returns were in April and in January respectively for BIST-100 index. In, 2010 and 2011 BET index achieved its highest return in July and October, whereas the lowest returns were in May and September respectively. For the same years, the highest returns were in July and March, whereas lowest returns were recorded in February and August in 2010 and 2011, respectively. In 2012 and 2013, BET index recorded its highest rates of return in February (10.5\%) and in January (10.9\%). Lowest returns of BET index returns were recorded in May and October for the same years. BIST index achieved its highest rates of return in June (12.7\%) and September (11.5\%). BIST index recorded its lowest rates of return in May and June for 2012 and 2013 respectively. Finally, BET index achieved its highest rates of return in June (4.9\%), whereas the index dropped to its lowest level with a loss of 5.9\% in October. BIST-100 index recorded its highest rates of return in March (10.9\%), and lowest rates of return in January with a loss of 9.2\% for 2012 and 2013 respectively. BET and BIST-100 index returns are shown in below Figure 1. It is surprising that BET and BIST-100 index returns show quite similar pattern for the time period analyzed. This pattern may imply that these markets are highly correlated or may be driven by the same economic factors.

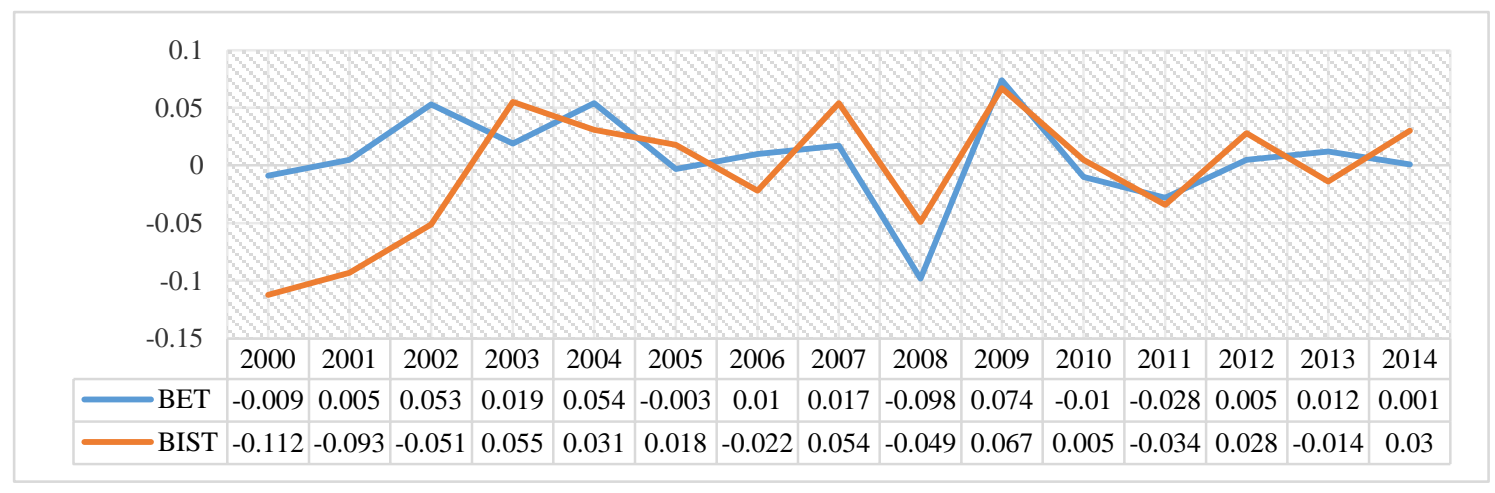

Figure 1. Average returns of BET and BIST100 index

Return rates in January are used to calculate the $R_{j}$ value which are shown in Table-3 below for the time period between 2000 and 2014.

Table 3. $R_{j}$ Values for BET and BIST-100 Index

\begin{tabular}{ccccc}
\hline Years & $\mathbf{R}_{\mathbf{J}}=\left(\mathbf{1}+\mathbf{R}_{\mathbf{m j}}\right)^{\mathbf{1 2}}$ & $R_{j}(\mathbf{B E T})$ & $\mathbf{R}_{\mathbf{J}}=\left(\mathbf{1}+\mathbf{R}_{\mathbf{m j}}\right)^{\mathbf{1 2}}$ & $R_{j}(\mathbf{B I S T})$ \\
\hline $\mathbf{2 0 0 0}$ & $(1+0.272)^{12}$ & 17.941 & $(1-0.074)^{12}$ & 0.397 \\
$\mathbf{2 0 0 1}$ & $(1+0.066)^{12}$ & 2.153 & $(1+0.11)^{12}$ & 3.498 \\
$\mathbf{2 0 0 2}$ & $(1-0.006)^{12}$ & 0.93 & $(1+0.038)^{12}$ & 1.564 \\
$\mathbf{2 0 0 3}$ & $(1+0.046)^{12}$ & 1.715 & $(1+0.048)^{12}$ & 1.755 \\
$\mathbf{2 0 0 4}$ & $(1+0.05)^{12}$ & 1.796 & $(1-0.065)^{12}$ & 0.446 \\
$\mathbf{2 0 0 5}$ & $(1+0.206)^{12}$ & 9.466 & $(1+0.078)^{12}$ & 2.463 \\
$\mathbf{2 0 0 6}$ & $(1+0.207)^{12}$ & 9.561 & $(1+0.132)^{12}$ & 4.427 \\
$\mathbf{2 0 0 7}$ & $(1-0.002)^{12}$ & 0.976 & $(1+0.051)^{12}$ & 1.816 \\
$\mathbf{2 0 0 8}$ & $(1-0.265)^{12}$ & 0.025 & $(1-0.253)^{12}$ & 0.03 \\
$\mathbf{2 0 0 9}$ & $(1-0.401)^{12}$ & 0.002 & $(1-0.107)^{12}$ & 0.257 \\
$\mathbf{2 0 1 0}$ & $(1+0.061)^{12}$ & 2.035 & $(1+0.022)^{12}$ & 1.298 \\
$\mathbf{2 0 1 1}$ & $(1+0.083)^{12}$ & 2.603 & $(1-0.099)^{12}$ & 0.286 \\
$\mathbf{2 0 1 2}$ & $(1+0.090)^{12}$ & 2.974 & $(1+0.109)^{12}$ & 3.031 \\
$\mathbf{2 0 1 3}$ & $(1+0.109)^{12}$ & 3.030 & $(1+0.007)^{12}$ & 2.738 \\
$\mathbf{2 0 1 4}$ & $(1+0.028)^{12}$ & 2.796 & $(1-0.092)^{12}$ & 2.480 \\
\hline
\end{tabular}


It is seen in Table 3 that the highest $R_{j}$ value (17.941) for BET index is observed in January in 2000. BET index dropped to its lowest level in 2009 with a rate of 0.002. BIST-100 index achieves its highest $R_{j}$ value (4.427) in January in 2006, whereas $R_{j}$ value dropped to its lowest level (0.03) in 2008. It is worth to notice that the lowest $R_{j}$ observed in 2008 and 2009 are mostly due to the global financial crises struck in 2008 and became more apparent in 2009. Annual $R_{j}$ value for the month of January are shown in Figure-2.

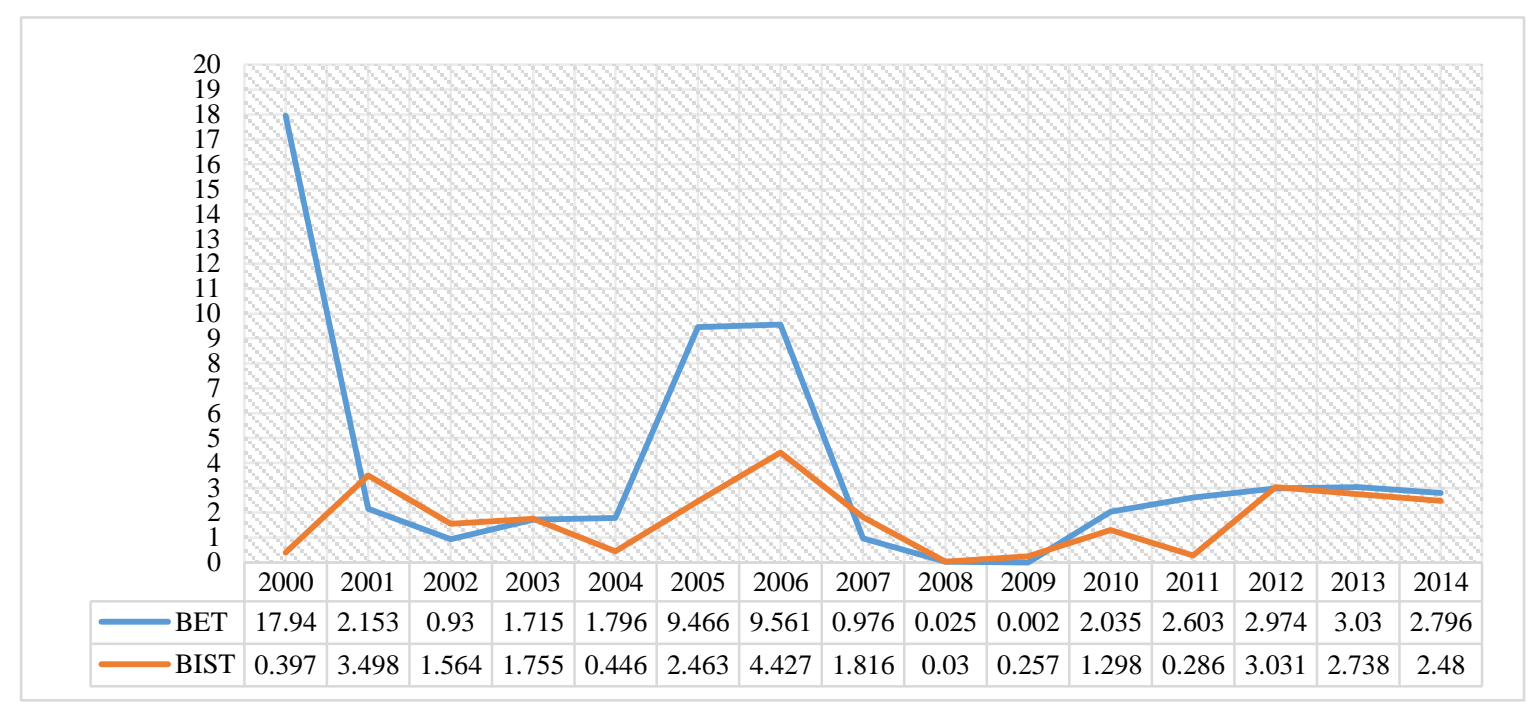

Figure 2. $R_{j}$ index values for BET and BIST-100 index

After examining $R_{j}$ value for the month of January, we calculate the returns in the remaining months of the year which is represented as $R_{y}$ and shown in Table 4 for the period 2000-2014.

Table 4. $R_{y}$ values for BET and BIST-100 index

\begin{tabular}{lcccc}
\hline Years & $\begin{array}{c}\text { Average BET Index Returns of the Months } \\
\text { other than January }\end{array}$ & $R_{y}(\mathbf{B E T})$ & $\begin{array}{c}\text { Average BIST-100 Index Returns of } \\
\text { the Months other than January }\end{array}$ & $R_{y}$ (BIST) \\
\hline $\mathbf{2 0 0 0}$ & -0.009 & 0.991 & -0.112 & 0.888 \\
$\mathbf{2 0 0 1}$ & 0.005 & 1.005 & -0.093 & 0.907 \\
$\mathbf{2 0 0 2}$ & 0.053 & 1.053 & -0.051 & 0.949 \\
$\mathbf{2 0 0 3}$ & 0.019 & 1.019 & 0.055 & 1.055 \\
$\mathbf{2 0 0 4}$ & 0.054 & 1.054 & 0.031 & 1.031 \\
$\mathbf{2 0 0 5}$ & -0.003 & 0.997 & 0.018 & 1.018 \\
$\mathbf{2 0 0 6}$ & 0.010 & 1.01 & -0.022 & 0.978 \\
$\mathbf{2 0 0 7}$ & 0.017 & 1.017 & 0.054 & 1.054 \\
$\mathbf{2 0 0 8}$ & -0.098 & 0.902 & -0.049 & 0.951 \\
$\mathbf{2 0 0 9}$ & 0.074 & 1.074 & 0.067 & 1.067 \\
$\mathbf{2 0 1 0}$ & -0.010 & 0.99 & 0.005 & 1.005 \\
$\mathbf{2 0 1 1}$ & -0.028 & 0.972 & -0.034 & 0.966 \\
$\mathbf{2 0 1 2}$ & 0.005 & 1.005 & 0.028 & 1.028 \\
$\mathbf{2 0 1 3}$ & 0.012 & 1.012 & -0.014 & 0.986 \\
$\mathbf{2 0 1 4}$ & 0.001 & 1.001 & 0.030 & 1.030 \\
\hline
\end{tabular}

$R_{y}$ values are calculated by adding 1 to the average return of the months other than January. It is seen that the highest calculated $R_{y}$ value for BET index is in January in 2009. It is also seen that BET index dropped to its lowest level in 2008 with a rate of 0.902 . On the other hand, BIST-100 index achieves its highest $R_{y}$ value (1.067) in 2009 , whereas $R_{y}$ value dropps to its lowest level (0.888) in 2000. $R_{y}$ values for both BET and BIST-100 index are shown in Figure 3. 


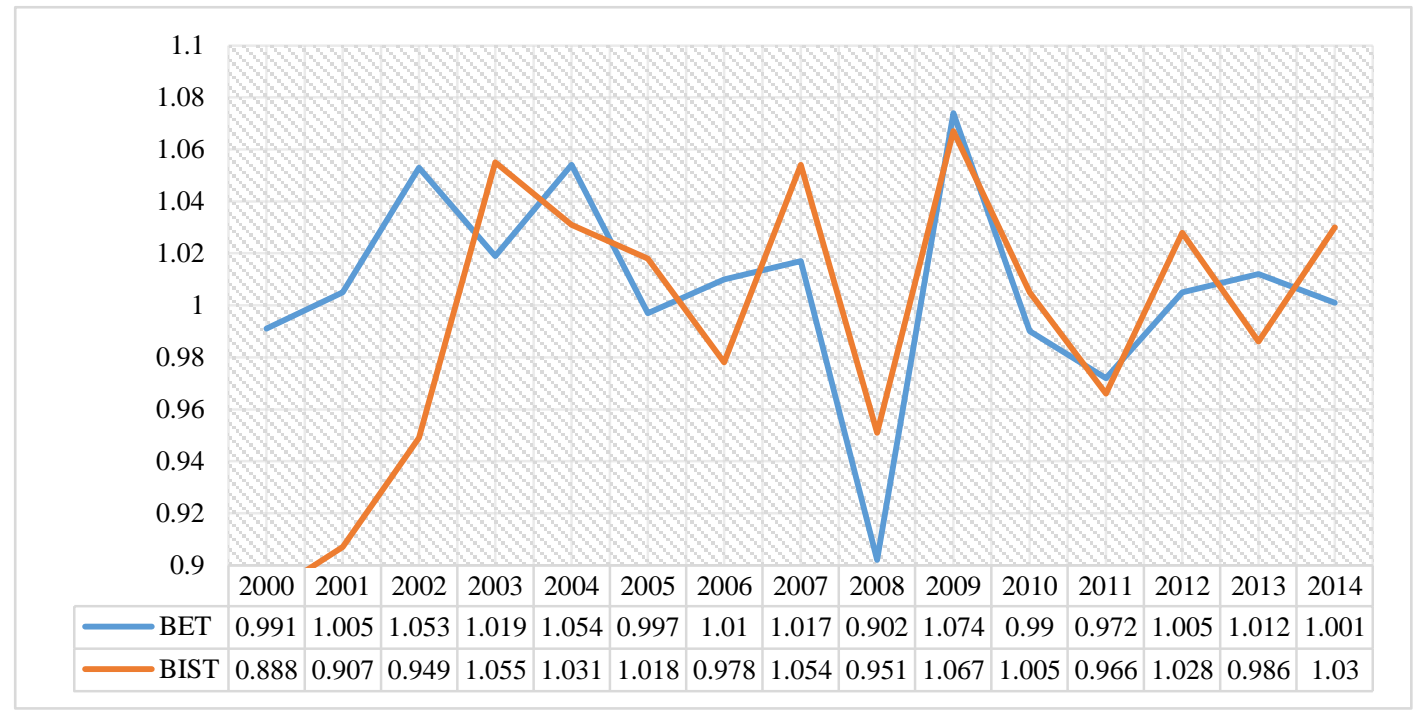

Figure 3. $\mathrm{R}_{\mathrm{y}}$ index values for BET and BIST-100 index

At least half of the power ratios which are given in Table 5 below for the time period analysed must be greater than 1 to ensure that January effect exist in that market.

Table 5. Power ratios for BET and BIST-100 index

\begin{tabular}{ccccc}
\hline Years & $\mathrm{R}_{\mathrm{j}} / \mathrm{R}_{\mathrm{y}}$ & Power Ratio (BET) & $\mathrm{R}_{\mathrm{j}} / \mathrm{R}_{\mathrm{y}}$ & Power Ratio (BIST) \\
\hline $\mathbf{2 0 0 0}$ & $17.941 / 0.991$ & 18.104 & $0.397 / 0.888$ & 0.447 \\
$\mathbf{2 0 0 1}$ & $2.153 / 1.005$ & 2.142 & $3.498 / 0.907$ & 3.857 \\
$\mathbf{2 0 0 2}$ & $0.93 / 1.053$ & 0.884 & $1.564 / 0.949$ & 1.648 \\
$\mathbf{2 0 0 3}$ & $1.715 / 1.019$ & 1.683 & $1.755 / 1.055$ & 1.664 \\
$\mathbf{2 0 0 4}$ & $1.796 / 1.054$ & 1.704 & $0.446 / 1.031$ & 0.433 \\
$\mathbf{2 0 0 5}$ & $9.466 / 0.997$ & 9.495 & $2.463 / 1.018$ & 2.419 \\
$\mathbf{2 0 0 6}$ & $9.561 / 1.01$ & 9.466 & $4.427 / 0.978$ & 4.527 \\
$\mathbf{2 0 0 7}$ & $0.976 / 1.017$ & 0.96 & $1.816 / 1.054$ & 1.723 \\
$\mathbf{2 0 0 8}$ & $0.025 / 0.902$ & 0.028 & $0.03 / 0.951$ & 0.032 \\
$\mathbf{2 0 0 9}$ & $0.002 / 1.074$ & 0.002 & $0.257 / 1.067$ & 0.241 \\
$\mathbf{2 0 1 0}$ & $2.035 / 0.99$ & 2.056 & $1.298 / 1.005$ & 1.292 \\
$\mathbf{2 0 1 1}$ & $2.603 / 0.972$ & 2.678 & $0.286 / 0.966$ & 0.296 \\
$\mathbf{2 0 1 2}$ & $2.974 / 1.005$ & 2.960 & $3.031 / 1.028$ & 2.947 \\
$\mathbf{2 0 1 3}$ & $3.030 / 1.012$ & 2.994 & $2.738 / 0.986$ & 2.776 \\
$\mathbf{2 0 1 4}$ & $2.796 / 1.001$ & 2.792 & $2.480 / 1.030$ & 2.409 \\
\hline
\end{tabular}

January effect is observed for all years except for 2002, 2007, 2008 and 2009 for BET index. These results indicate that January effect is persistent for BET index. It is seen in Table 5 that BET index achieves its highest power ratio rate in 2000 by 18.104 . However, the power ratio dropped to its lowest level of 0.002 in 2009. It is also seen that January effect also exist for BIST-100 index for all years except for 2004, 2008 and 2009. BIST-100 index power ratio reaches a record high of 4.557 in 2006, whereas dropped to its lowest level of 0.032 in 2008. Power ratios for both index are also presented in Figure 4. 


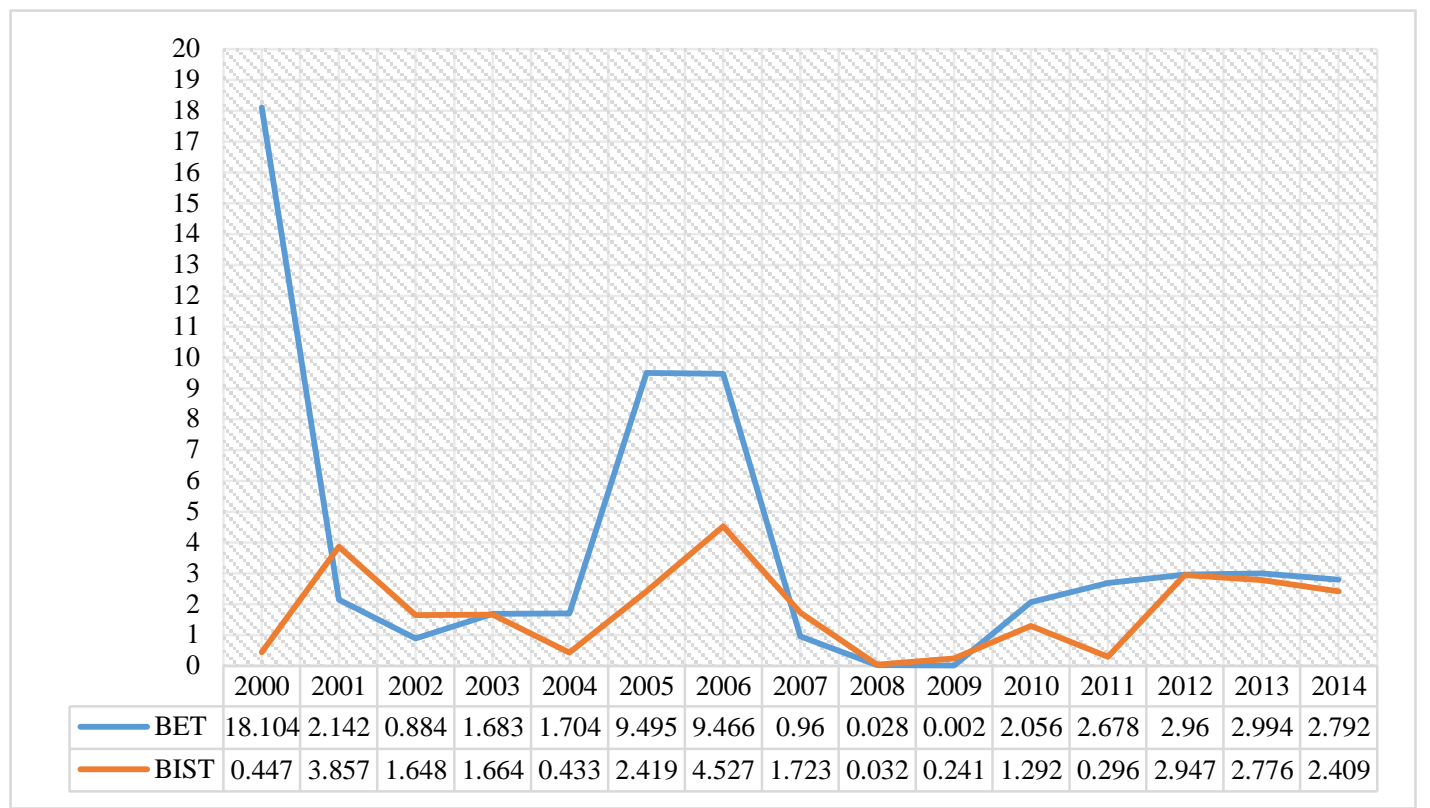

Figure 4. Power ratios for BET and BIST-100 index

In other words, our analysis show that the number of power ratios greater than 1 is 11 out of 15 years $(73.3 \%)$ for BET index, and for 10 out of the 15 years $(66.6 \%)$ for BIST-100 index. As a result, it is possible to say that a persistent January effect exist for both BEST and BIST-100 index.

\section{Conclusions}

In an efficient market, prices reflect all available information. In this respect, it is impossible to get abnormal return consistently in an efficient market. However, it is possible to see abnormal returns in many stock markets in practice. Previous studies have shosn that majority of these abnormal returns can be explained by calendar or return anomalies. In this paper, we examine January effect in order to explain the abnormal returns observed in January. Using daily closing price of Bucharest Exchange Trading (BET) and BIST-100 index, we analyse January effect with power ratio approach. Results indicate that January effect exist for $11(2000,2001,2003,2004,2005$, 2006, 2010, 2011, 2012, 2013 and 2014) of the 15 years for BET and $10(2001,2002,2003,2005,2006,2007$, 2010, 2012, 2013 and 2014) of the 15 years for BIST-100 index. In other words, a persistent January effect is found for both BET and BIST-100 index. We think that tax-loss selling hypothesis, increasing money supply, new information in January may be the underlying reasons of the survival of the January effect in these markets. Fo future studies, this study may be improved by adding new data of developing and developed markets. Future studies may also focus on remaining calendar anomalies and compare the results with those of similar studies.

\section{References}

Alrabadi, D. W. H., \& AL-Qudah, K. A. (2012). Calendar Anomalies: The Case of Amman Stock Exchange. International Journal of Business and Management, 7(24), 120-127. https://doi.org/10.5539/ijbm.v7n24p120

Angrawal, A., \& Tandon, K. (1994). Anomalies or Illusions? Evidence From Stock Markets in Eighteen Countries. Journal of International Money and Finance, (13), p. 83-106. https://doi.org/10.1016/0261-5606(94)90026-4

Atakan, T. (2008). İstanbul Menkul Kıymetler Borsası'nda Haftanın Günü Etkisi ve Ocak Ayı Anomalilerinin Arch-Garch Modelleri ile Test Edilmesi. İstanbul Üniversitesi Isşletme Fakültesi Dergisi, 37(2), 100.

Aytekin, S., \& Sakarya, Ş. (2014). Ocak Ayı Anomalisi: Borsa Istanbul Endeksleri Üzerine Bir Uygulama. Uluslararası Yönetim Íktisat ve İsletme Dergisi, 10(23). https://doi.org/10.17130/ijmeb.2014.10.23.683

Banz, R. W. (1981). The Relationship Between Return and Market Value of Common Stocks. Journal of Financial Economics, (9), 3-18. https://doi.org/10.1016/0304-405X(81)90018-0

Berges, A., Mcconnel, J. J., \& Schlarbaum, G. G. (1984). Turn-of-The-Year Effect in Canada. Journal of Finance, (39), 185-192. https://doi.org/10.1111/j.1540-6261.1984.tb03867.x

Bohl, M. T., \& Salm, C. A. (2010). The Other January Effect: International Evidence. The European Journal of Finance, 16(2), 173-182. https://doi.org/10.1080/13518470903037953 
Borsa İstanbul. (2015). Retrieved from http://www.borsaistanbul.com/

Branch, B. (1977). A Tax Loss Trading Rule. Journal of Business, (50), 1198-1207. https://doi.org/10.1086/295930

Çinko, M. (2008). İstanbul Menkul Kiymetler Borsasinda Ocak Ayi Etkisi. Doğuş Üniversitesi Dergisi, 9(1), 47-54.

Corhay, A., Hawawını, G., \& Michei, P. (1987). Seasonality in The Risk-Return Relationship: Some International Evidence. Journal of Finance, (42), 49-68. https://doi.org/10.1111/j.1540-6261.1987.tb02549.x

Dyl, E. A. (1977). Capital Gain Taxation and Year-End Stock Market Behavior. Journal of Finance, (32), 165-175. https://doi.org/10.1111/j.1540-6261.1977.tb03250.x

Givoly, D., \& Ovadia, A. (1983). Year-End Tax-Induced Sales and Stock Market Seasonality. Journal of Finance, (38), 171-186. https://doi.org/10.1111/j.1540-6261.1983.tb03633.x

Gu, A. Y. (2003). The Declining January Effect: Evidences From the U.S. Equity Markets. The Quarterly Review of Economics and Finance, (43), 395-404. https://doi.org/10.1016/S1062-9769(02)00160-6

Gültekin, M. N., \& Gültekin, N. B. (1983). Stock Market Seasonality: International Evidence. Journal of Financial Economics, (12), 469-482. https://doi.org/10.1016/0304-405X(83)90044-2

Ho, Y. K. (1990). Stock Return Seasonalities in Asia Pacific Markets. Journal of International Financial Management \& Accounting, 2(1), 47-77. https://doi.org/10.1111/j.1467-646X.1990.tb00017.x

Karan, M. B. (2004). Yatırım Analizi ve Portföy Yönetimi. Ankara: Gazi Kitabevi.

Keim, D. B. (1983). Size Related Anomalies and Stock Return Seasonality: Further Empirical Evidence. Journal of Financial Economics, (12), 13-32. https://doi.org/10.1016/0304-405X(83)90025-9

Keong, L. B., Yat, D. N., Ching, L., \& Chong, H. (2010). Month-of-The-Year Effects in Asian Countries: A 20-Year Study (1990-2009). African Journal of Business Management, 4(7), 1351-1362.

Küçüksille, E. (2012). İMKB Endekslerinde Ocak Ayı Etkisinin Test Edilmesi. Muhasebe ve Finansman Dergisi, 129-138.

Officer, R. R. (1975). Seasonality in The Australian Capital Markets: Market Efficiency and Empirical Issues, Journal of Financial Economics, (2), 29-52. https://doi.org/10.1016/0304-405X(75)90022-7

Özer, G., \& Özcan, M. (2002). İMKB'da Ocak Etkisi, Etkinin Sürekliliği, Firma Büyüklüğü ve Portföy Denkleştirmesi Üzerine Deneysel Bir Araştırma. Süleyman Demirel Üniversitesi, I.İ.B.F. Dergisi, 3(2), 133-158.

Reinganum, M. R. (1983). The Anomalous Stock Market Behavior of Small Firms in January: Empirical Tests For Tax-Loss Selling Effects. Journal of Financial Economics, (12), 89-104. https://doi.org/10.1016/0304-405X(83)90029-6

Rozeff, M. S., \& Kinney, W. R. (1976). Capital Market Seasonality: The Case of Stock Returns. Journal of Financial Economics, (3), 379-402. https://doi.org/10.1016/0304-405X(76)90028-3

Santesmases, M. (1986). An Investigation of The Spanish Stock Market Seasonalities, Journal of Business Finance and Accounting, (13), 267-276. https://doi.org/10.1111/j.1468-5957.1986.tb00096.x

The Bucharest Stock Exchange. (2015). Retrieved from http://www.bvb.ro/

Van Den Bergh, W. M., \& Wessels, S. E. (1985). Stock Market Seasonality and Taxes: An Examination of The Tax-Loss Selling Hypothesis. Journal of Business and Accounting, (12), 515-530. https://doi.org/10.1111/j.1468-5957.1985.tb00791.x

Wachtel, S. (1942). Certain Observations on Seasonal Movement in Stock Prices. Journal of Business, (15), 184-193. https://doi.org/10.1086/232617

\section{Copyrights}

Copyright for this article is retained by the author(s), with first publication rights granted to the journal.

This is an open-access article distributed under the terms and conditions of the Creative Commons Attribution license (http://creativecommons.org/licenses/by/4.0/). 